\title{
Implemetasi Pendidikan Karakter Melalui Media Dongeng Berbasis Visual Pada Anak Usia 4-6 Tahun
}

\author{
Aprilia Triaristina ${ }^{1}$, Hamid Mukhlis ${ }^{2}$ \\ ${ }^{1}$ Departemen Ilmu Pengetahuan Sosial, Fakultas Keguruan dan Ilmu Pendidikan, Universitas Lampung \\ ${ }^{2}$ Program Studi Psikologi, Fakultas Sosial Bisnis, Universitas Aisyah Pringsewu \\ e-mail: ${ }^{1}$ liaforkia@gmail.com, ${ }^{2}$ me@hamid.mukhlis.id
}

\begin{abstract}
Abstrak. Pendidikan Karakter merupakan suatu cara untuk menghasilkan seseorang atau siswa yang mempunyai kecerdasan akademik dan moral. Sampai saat ini pendidikan karakter masih sangat diperlukan karena untuk mengatasi rendahnya nilai moral yang selalu mengalami peningkatan. Lembaga pendidikan yang berbasis formal maupun informal harus saling bersinergi untuk membiasakan pendidikan karakter pada anak. Penerepan pendidikan karakter sebaiknya dilakukan sejak dini karena merupakan langkah yang tepat, masa ini disebut masa keemasan untuk meletakan nilai dasar karakter yang berguna untuk masa depannya. Dibutuhkan sebuah media untuk megaplikasikan pendidika karakter pada anak usia 4-6 tahun. Dongeng merupakan salah satu pendekatan pembelajaran yang relevan dan menyenangkan karena anak masih suka berimajinasi dalam menilai pendidikan moral. Penanaman pendidikan karakter bisa ditanamkan kepada anak amelalui cerita atau dongeng dengan mempelajari karakter atau sifat yang ada pada dongeng tersebut. Pendongeng bisa menggunakan media visual serta bahasa yang disampaikan tentunya telah dipilih atau diciptakan untuk dapat tampilan dalam bentuk menarik sederhana, jelas, ekonomis, dan inovatif untuk menghindari kesalahan persepsi oleh anak terhadap materi atau pesan yang ingin disampaikan. Penelitian ini menggunakan metode penelitian kualitatif (qualitative research) dengan menggunakan pendekatan studi kasus penelitian menggunakan teknik "snowball sampling terhadap pendidik, anak, kepala lembaga,orang tua. Tujuan jangka panjang penelitian ini adalah untuk menanamkan pendidikan karakter pada siswa usia pra sekolah melalui dongeng berbasis visul, dengan cara memberikan sosialisasi dan pelatihan kepada terhadap pendidik, anak, kepala lembaga,orang tua.
\end{abstract}

Kata kunci: Pendidikan Karakter, Dongeng Berbasis Visual, Anak Usia 4-6 Tahun

\section{Pendahuluan}

Undang-undang No tahun 2003 menjelaskan bahwa tujuan pendidikan nasional adalah untuk membangun potensi peserta didik agar menjadi manusia yang beriman dan bertaqwa kepada Tuhan Yang Maha Esa, berakhlak mulia, sehat,berilmu, cakap, kreatif, mandiri dan menjadi warga negara yang demokratis serta tanggung jawab. Pentingnya mengembangkan karakter pada anak, agar mereka menjadi pribadi yang baik merupakan salah satu misi penting dalam pendidikan (Brayan 2005). Pendidikan karakter ini bukan merupakan suatu hal baru di Indonesia. Pernah dijumpai pendidikan nilai yang ditanam dalam bentuk penghayatan dan pengalaman pancasila (Samani dan Hariyanto, 2013). Era saat ini pendidikan nilai tersebut muncul dengan sebutan pendidikan karakter.

Melihat situasi dan kondisi lembaga sekolah tersebut, membuktikan bahawa penanaman pendidikan karakter masih perlu diperbaiki. Perlu diperbaiki karena belum sesuai dengan standar atau acuan ideal. Ada pendapat yang mengatakan tentang idealnya penerapan pendidikan karakter, pertama pengembangan diri anak dilakukan secara holistik yang meliputi aspek kecerdasan intelektual, emosional dan spiritual. (Zohar dan Marshal 2000) menyebutkan bahwa tanpa adanya aspek spiritual ini tidak mungkin seseorang dapat menangkap makna hidup (Zuchdi, dkk, 2013). Kedua penyediaan 
fasilitas dan sumber belajar memadai (Mulyasa, 2013). Ketiga keseluruhan proses pendidikan karakter seharusnya dilaksanakan dalam semua aspek kehidupan baik dirumah,lembaga maupun masyarakat (Zuchdi, dkk, 2013). Keempat penggunaan strategi permodelan atau pemberian teladan bagi anak.

Selama bertahun-tahun dongeng telah memperkuat sikap pembaca terhadap kehidupan,terhadap hubungan manusia dan menuju moral yang baik Bryan (2005). Nilai karakter warga Amerika Serikat dapat dibentuk dengan sebuah cerita maupun dongeng. Karya sastra yang tidak dibatasi oleh waktu, perbedaan budaya, ekonomi,tingkatan generasi ini mampu mencetak warga negara reflektif dan prihatin yang memiliki pengetahuan, keterampilan dan sikap yang melambangkan dan melestarikan masyrakat yang demokratis sebagai inti dari warga negara yang efektif (Sanchez dkk, 2006).

Berdasarkan fenomena diperlukan penelitian untuk mengetahui implementasi pendidikan karakter dengan menggunakan media dongeng berbasis visual pada anak usia 4-6 tahun.

\section{Metode}

Jenis penelitian yang dilakukan adalah penelitian kualitatif (qualitative research) dengan menggunakan pendekatan studi kasus penelitian menggunakan teknik "snowball sampling terhadap pendidik, anak, kepala lembaga,orang tua. Pengambilan data dilakukan pada bulan maret sampai bulan mei tahun 2019. Untuk memperoleh data yang diperlukan dalam penelitian ini, teknik yang akan digunakan yaitu wawancara dan observasi.

\section{Hasil dan Pembahasan}

\section{Program Pembelajaran}

Program pembelajaran yang dirancang untuk tujuan terciptanya esensi bermain pada pembelajaran berasal dari standar pendidikan anak usia dini, yaitu kurikulum 2013 yang telah disusun dan disesuaikan dengan kondisi Taman Kanak-Kanak Aisyiyah 1 Pringsewu. Metode pembelajaran menggunakan metode sentra. Metode sentra adalah metode pembelajaran yang didalam proses pembelajarannya dilakukan didalam lingkaran (circle times) dan sentra bermain. Setiap sentra mendukung perkembangan anak dalam tida jenis bermain, yaitu bermain sensorimotor atau fungsional, bermain peran, dan bermain konstruksi. Sentra yang disuguhkan oleh Taman Kanak-Kanak Aisyiyah 1 Pringsewu sentra berikut: 1) sentra persiapan, 2) sentra seni, 3) sentra bermain peran, 4) sentra balok.

Disamping program pembelajaran dalam kelas, Taman Kanak-Kanak Aisyiyah 1 Pringsewu juga memiliki beberapa program kegiatan penunjang, program ekstrakurikuler dan program tambahan. Adapun program penunjang terdiri dari, peringatan hari besar islam (kegiatan bulan puasa, zakat fitrah,) peringatan hari besar nasional (lomba-lomba dalam rangka peringatan HUT RI, lomba dalam rangka hari Kartini,), kegiatan tengah semester wisata air atau berenang di kolam renang yang dekat dengan sekolah, dan kegiatan atau lomba yang disesuaikan dengan program IGTKI). Selain menunjang kurikuler juga bertujuan untuk menggali dan mengembangkan bakat dan minat anak meliputi kegiatan da'i cilik drumband, dan mewarnai. Biasanya kegiatan tersebut dilakukan untuk berkompetisi antar sekolah Taman Kanak-Kanak. Sedangkan program tambahan diberikan kepada peserta didik Aisyiyah 1 Pringsewu B berupa pengenalan huruf untuk bekal masuk jenjang pendidikan dasar.

\section{Implementasi Pendidikan Karakter Melalui Dongeng Bebasis Visual}


Mendongeng telah menjadi kebiasaan di TK Aisyiyah 1 Pringsewu Lembaga ini menjadikan teknik bercerita tersebut untuk menanamkan nilai karakter positif pada anak. Mengingat anak usia dini yang dalam perkembangan moralnya masih dipengaruhi oleh fantasi, maka penggunaan dongeng relevan untuk membiasakan anak melakukan nilai kebaikan (Mansur, 2011: 49). Dalam penerapannya dibagi dengan tahapan pengenalan (moral knowing), dan merasakan serta melakukan (moral feeling dan moral action) (Lickona, 1991). Langkah yang dipilih tersebut sebagai strategi untuk menjadikan nilai karakter menjadi kebiasaan bagi anak baik di rumah maupun di lembaga pendidikan.

Pelaksanaan memperkenalkan nilai ini dibagi dalam dua tahapan yaitu dongeng sebagai hiburan, dan sebagai pendidikan karakter. Dongeng yang berfungsi sebagai hiburan, maka dalam penyampaiannya ada beragam jenis dongeng biasa, fabel, sage, mite atau cerita gaib, dan legenda. Media yang digunakan dapat tokoh anak langsung, boneka tangan, visual maupun alat peraga bebas. Berbagai variasi jenis dongeng, media, serta metode pendukung dihadirkan supaya anak merasa tidak bosan dan senang dengan cerita yang disampaikan lewat dongeng.

Aspek dalam pendidikan karakter dongeng tersebut bermuatan nilai- nilai karakter. Nilai karakter tersebut selanjutnya dirasakan (moral feeling) dan dibiasa kan pada anak (moral action). Bentuk pelaksanaannya adalah dengan menggunakan metode pembiasaan, keteladanan, bermain peran, pemberian reward. Pembiasaan nilai karakter yang baik selalu diajarkan kepada anak supaya mereka terbiasa dan menjadi kebudayaan dalam hidupnya. Keteladanan dicontohkan oleh semua stakeholder yang ada di lembaga seperti guru, kepala lembaga, dan karyawan. bermain peran digunakan supaya anak dapat merasakan tentang nilai karakter yang baik, sehingga pada saat yang nyata mereka menjadi terbiasa. Adapun un- tuk reward sebagai sarana dongeng, variasi media dongeng, serta adanya metode pendukung. Jenis dongeng diantaranya untuk menstimulasi anak supaya mau melakukan nilai karakter yang baik.

Tahap evaluasi dilakukan secara berkelanjutan dengan menggunakan penilaan proses dan hasil. Penilaian proses untuk mengamati proses anak dalam melakukan nilai karakter tersebut, sedangkan hasil akan terlihat dalam rutinitas anak dalam menjalankan nilai tersebut. Teknik penilaian yang digunakan diantaranya observasi, penugasan, pencatatan anekdot, laporan orang tua, dan deskripsi profil anak.

\section{Nilai Karakter yang Disampaikan Melaui Dongeng}

Nilai karakter yang di TK Aisyiyah 1 Pringsewu dikembangkan dengan cara menyampaikan sejumlah dongeng yang berisi tentang beberapa nilai karakter. Dongeng berkarakter setiap pagi hari disampaikan kepada anak supaya mereka mau meniru dalam kehidupan sehari-hari. Tahapan selanjutnya setelah anak mengetahui nilai karakter dari dongeng, maka implementasinya anak dibiasakan dengan nilai karakter tersebut. Adapun untuk nilai karakter dikelompokan dalam emapt nilai, yaitu nilai berdasar olah hati, olah pikir, olah raga, dan olah rasa. Nilai berdasarkan olah hati yang terdiri atas kecintaan terhadap Tuhan, kejujuran, tanggungjawab, dan rendah hati. Olah pikir terdiri atas nilai kreativitas, olah raga diantaranya nilai mandiri, percaya diri, dan disiplin. Adapun olah rasa dan karsa terdiri atas kerja sama, hormat dan santun, toleransi, cinta tanah air, kepemimpinan, peduli lingkungan, serta kerja keras.

\section{Hasil Pendidikan Karakter}

Pendidikan karakter adalah pendidikan yang diusahakan dan direncanakan untuk menanamkan dan mengembangkan nilai-nilai karakter/moral/akhlak kepada peserta didik sehingga mereka dapat mengetahui kebaikan, mencintai kebaikan dan melakukan kebaikan sebagai anggota masyarakat, warga 
negara yang nasionalis, religius, produktif dan kreatif. Pelaksanaan nilai-nilai karakter bagi anak usia dini pada Taman Kanak-Kanak Aisyiyah 1 Kelompok B3 dilakukan melalui kegiatan yang terprogram dan pembiasaan. Kegiatan terprogram dilaksanakan di dalam kelas, sedangkan pembiasaan dilakukan mulai dari masuk sekolah sampai pulang sekolah.

Kegiatan terprogram mengacu pada RKH (Rencana Kegiata Harian) atau RPPH (Rencana Pelaksanaan Pembelajaran Harian) yang dibuat oleh pendidik. Berdasarkan kajian RPPH Taman Kanak-Kanak Aisyiyah 1 Kelompok B3, kegiatan pembelajaran memiliki 4 pijakan, yaitu pijakan lingkungan, pijakan sebelum main, pijakan saat main, dan pijakan setelah main. RPPH juga dilengkapi dengan rencana evaluasi tentang nilai-nilai yang telah dicapai peserta didik.

Penelitian ini dilaksanakan di kelas B3 Taman Kanak-Kanak Aisyiyah 1 Pringsewu. Melalui teknik observasi dan wawancara ditemukan jawaban dari pertanyaan penelitian. Dari hasil penelitian ini berupa hasil wawancara dengan guru sebagai subyek penelitian. Berikut data wawancara dengan guru di kelas B3 mengenai implementasi pendidikan karakter berbasis dongeng pada anak usia 4-6 tahun. Pada bagian ini merupakan hasil wawancara peneliti dengan guru di kelas B3 yang berkaitan dengan implementasi pendidikan karakter religius, peduli sosial dan kerja keras dan kendala yang dihadapi oleh guru pada anak usia 4 -6 tahun di Taman Kanak-Kanak Aisyiyah 1 Pringsewu.

Dari hasil wawancara dengan guru kelas B3 yang bernama Eni Purwanti dan Apriyani diketahui bahwa guru kelas mengimplementasikan pendidikan karakter berbasis dongeng. Guru menyatakan bahwa guru telah mengimplementasikan pembacaan dongeng untuk pendidikan karakter yang telah diberlakukan Pemerintah saat ini. Adapun dongeng yang dibacakan untuk mengembangkan karakter religius, peduli sosial dan kerja keras. Guru menyadari dongeng dianggap cara yang efektif dalam pendidikan karakter karena dengan cerita anak-anak sangat senang. Dongeng yang sering dibacakan oleh guru yaitu sesuai dengan tema di sekolah kemudian dikembangkan dengan cerita-cerita. Namun dongeng yang biasadigunakan oleh guru yaitu dongeng binatang-binatang.

Dari hasil wawancara dengan guru kelas B3 yang bernama Eni Purwanti dan Apriyani diketahui bahwa guru telas mengimplementasikan pendidikan karakter berbasis dongeng. Guru menyatakan bahwa guru telah mengimplementasikan pembacaan dongeng untuk pendidikan karakter yang telah diberlakukan Pemerintah saat ini. Adapun dongeng yang dibacakan untuk mengembangkan karakter religius, peduli sosial dan kerja keras. Guru menyadari pentingnya pendidikan karakter supaya anak itu membentuk pribadi hingga dia besar sehingga mereka menyerapi karakter yang baik-baik sebagaimana telah diajarkan. Pendidikan karakter harus diberikan kepada anak usia dini karena dari kecil terutama tidak dari sekolah saja, seharusnya dibentuk dari rumah bagaimana dia bersikap, berprilaku dan di TK atau di PAUD tinggal kita menguatkannya memberinya pelajaran-pelajaran karakter-karakter yang harus mereka miliki sejak dini. Adapuncara guru menerapkan pendidikan karakter yaitu dengan cara guru bersikap, memperlakukan mereka datang ke sekolah kita sambut, memberi salam bagaimana anak masuk ke kelas, mengucap salam ketika masuk kelas bertemu dengan ibu guru itu merupakan karakter menghormati dan menghargai dan didukung dengan cara mendongeng karena anak suka mendengarkan dongeng dan lebih mudah masuk ke akal mereka.

Dari hasil wawancara dengan guru kelas B3 yang bernama Eni Purwaanti dan Apriyanti diketahui bahwa pada karakter religius anak, kebanyakan anak belum dapat mengikuti pembacaan doa dengan benar masih banyak yang melamun dan tidak mengikuti mimik mulut mengikuti bacaan doa, bersikap lembut dan Tawadhu dan membiasakan diri berkata baik seperti Alhamdulillah, Astagfirullah, dan lain-lain). Adapun dongeng yang digunakan untuk mengembangkan karakter religius yaitu tentang tentang kisah-kisah nabi atau atau kisah-kisah agama, misalnya keagungan Allah, Amanah dari Allah, Nasihat dengan Kasih Sayang dan lain-lain. Adapun karakter religius seseorang karena karakter religius anak dibentuk dari lingkungan anak terutama keluarga 
yang sedari kecil menanamkan nilai-nilai religius pada anak. Penghambatnya tidak ada, anak-anak mendengarkan walaupun ada satu dua anak bermain namun mereka paham apa yang kita ceritakan.

Hasil wawancara dengan guru kelas B3 yang bernama Eni Purwanti dan Apriyanti diketahui bahwa pada karak terpeduli sosial, kebanyakan anak belum dapat berbagi makanan miliknya, berbagi mainan secara bersama-sama dan berbagi alat tulis dengan teman-temannya. Adapun dongeng yang digunakan untuk mengembangkan karakter peduli sosial adalah dongeng yang tentang kerja keras berarti sesuatu yang dilakukan tanpa putus asa, misalnya tentang semut rajin bergotong royong, mengumpulkan makanan bersama-sama. Adapun karakter peduli sosial anak dikelas B3 ini dapat dilihat dari keseharian anak dimulai dari sikap berbagi anak, saling membantu, dan mempunyai sikap sosial berhadap temannya. Karakter peduli sosial ini juga harus didukung oleh segenap lingkungan anak, terutama keluarga karena dari lahirlah anak dibentuk sesuai kepribadian orangtuanya, karena anak seperti kertas putih yang mencontoh setiap gerak oarng sekelilingnya. Sikap peduli sosial ini dapat dilihat dari bagaimana orang tua menanamkan nilai-nilai sosial. Misalnya berbagi barang miliknya ataupun berbagi barang sekolah secara bsesama-sama.

Hasil wawancara dengan guru kelas B3 yang bernama Eni Purwanti dan Apriyanti diketahui bahwa pada karakter kerja keras, kebanyakan anak belum dapat menyelesaikan semua tugas yang diberikan guru hingga selesai, mengerjakan sesuatu dengan gigih walau sulit, dan menyelesaikan permainan yang dimainkannya. Adapun dongeng yang digunakan untuk mengembangkan karakter kerja keras adalah dongeng yang tentang kerja keras berarti sesuatu yang dilakukan tanpa putus asa, misalnya tentang semut rajin bergotong royong, mengumpulkan makanan bersama-sama.Adapun karakter kerja keras anak di kelas B3, anak punya karakter ini karena kemampuan anak kan berbeda-beda. Namun kalau pada karakter kerja keras ini biasanya saya berikan tugas yang sedikit sulit setiap harinya, apalagi mereka sebentar lagi masuk SD jadi harus terbiasa mengerjakan yang sedikit rumit, namun apabila anak tidak bisa menyelesaikannya tetap dibantu. Karakter kerja keras ini juga didukung oleh segenap lingkungan anak, terutama keluarga. Karakter kerja keras ini dilihat dari bagaimana orang tua menanamkan kerja tanpa putus asa. Anak dilatih mengerjakan tugas lebih sulit setiap harinya.

Hal ini dimaksudkan agar anak terbiasa melakukan hal yang sulit karena sesuatu yang dilakukan dengan kerja keras dan gigih akan mendapatkan kesuksesan nantinya. Apabila guru memberikan tugas yang sulit dari bisanya dan kebanyakan anak belum bisa menyelesaikannya, guru membantu anak mengarahkan dan memberinya waktu lebih dalam menyelesaikan dengan cara memotong waktu makannya sehingga pada jam istirahat anak disuruh memakan makanan yang telah dibawanya dirumah. kesuksesan nantinya. Apabila guru memberikan tugas yang sulit dari bisanya dan kebanyakan anak belum bisa menyelesaikannya, guru membantu anak mengarahkan dan memberinya waktu lebih dalam menyelesaikan dengan cara memotong waktu makannya sehingga pada jam istirahat anak disuruh memakan makanan yang telah dibawanya dirumah.

Hasil wawancara dengan guru kelas B3 yang bernama Eni Purwanti dan Apriyanti diketahui bahwa faktor pendukung dan penghambat yang dialami oleh guru dalam pendidikan karakter berbasis dongeng ini adalah faktor pendukungnya, anak selalu antusias dalam mendengarkan setiap cerita, kata demi kata dan mendengarkan cerita hingga selesaiwalaupun ada penghambatnya yaitu jika ada anak yang tidak mendengarkan cerita, bermain asyik sendiri guru menasihatnya dan menanyakan kembali isi cerita pada anak, membawanya ke barisan depan agar tidak mengganggu teman-temannya. Selain itu, guru menanyakan mana perbuatan yang baik mana yang tidak dan mana yang perlu dicontoh dan mana yang tidak perlu di contoh dan mana yang tidak. Adapun kendala yang lain yaitu kurangnya buku-buku dongeng yang disediakan oleh yayasan. 


\section{Kesimpulan dan Saran}

Simpulan dari penelitian ini bahwa guru telah mengimplementaasikan pendidikan karakter dengan menggunakan dongeng. Adapun nilai-nilai karakter yang di impleentasikan adalah Religius, Peduli sosial, dan Kerja keras. Guru mendongeng dengan cara membacakan buku-buku cerita dan menggunakan boneka jari.

\section{Daftar Pustaka}

Arikunto, Sharsini. 2006. Prosedur Suatu Pendekatan Praktek. Jakarta: PT. Rienika Cipta

Bryan, L. 2005. Once upon a time; a grimm approach to character education. Journal of studies research, No.29, No.1.

Fathurrohman, Pupuh, Dkk. 2013. Pengembangan Pendidikan Karakter. Bandung: PT Refika Aditama.

Hornby, A.S. dan Parnwell, E.C. 1972. Learner's Dictionary. Kuala Lumpur: Oxford University Press

Kementrian Pendidikan Nasional. (2010). Grand design pendidikan karakter bangsa. Jakarta: Kemendiknas

Lickona, T. (1991). Educating for character, how our school can teach respect and responsibility. New York: Bantam Books.

Megawangi, Ratna. 2004. Pendidikan Karakter Solusi Yang Tepat Untuk Membangun Bangsa. Jakarta: Indonesia Heritage Foundation

Moleong, (2007). Metode Penelitian Kualitatif. Bandung: Remanja Rosdakarya 